\title{
Comparison of sustained attention skills of deaf athletes and non- athletes
}

\author{
Yunus Gür
}

Kahramanmaraş Sütçüimam University, School of Physical Education and Sports, Kahramanmaraş, Turkey, yunusgur123@gmail.com

Selçuk Gençay

Kahramanmaraş Sütçüimam University, School of Physical Education and Sports, Kahramanmaraş, Turkey, sgencay@ksu.edu.tr

Ercan Gür

Firat University, Sport Sciences Faculty, Elazı̆̆g, Turkey, egur23@gmail.com

\begin{abstract}
In this research it is aimed to compare the attention skills of hearing-impaired children playing sports and who do not. In total, 233 hearing-impaired children living in the cities; Malatya, Elazığ, Gaziantep and Istanbul participated to the research. SPSS program were used for statistical analysis of the data obtained in the study and the level of statistical significance was determined as $(\mathrm{p}<.05)$. At the end of the research, it has been found that the attention levels of hearing-impaired children who play sports show statistically significant difference according to their gender $(p<.05)$. As a result, it seems that when it is compared with hearing-impaired children who do not play sports, the demographic variables have a lower impact on the attention levels of the ones, who play sports.
\end{abstract}

Keywords Impairment, hearing impairment, children, sport, attention level

\section{İşitme engelli sporcuların sürekli dikkat becerilerinin sporcu olmayanlarla karşılaştırılması}

ÖZ Bu araştırmada, spor yapan işitme engelli çocuklar ile spor yapmayan işitme engelli çocukların dikkat becerilerinin karşılaştırılması amaçlanmıştır. Araştırmaya Malatya, Elazı ̆̆ Gaziantep ve İstanbul illerinde yaşayan toplam 233 işitme engelli çocuk katılmıştır. Araştırmada elde edilen verilerin istatistiksel analizlerinde SPSS programı kullanılmış ve istatistiksel açıdan anlamlılık düzeyi $(p<.05)$ olarak belirlenmiştir. Araştırmanın sonunda, spor yapan işitme engelli bireylerde, dikkat düzeyinin cinsiyete göre istatistiksel açıdan anlamlı farklılık gösterdiği tespit edilmiştir $(\mathrm{p}<.05)$. Sonuç olarak, spor yapmayan işitme engelli çocuklar ile kıyaslandığı zaman demografik değişkenlerin, spor yapan çocukların dikkat düzeyleri üzerinde daha düşük etkiye sahip olduğu söylenebilir. 


\section{INTRODUCTION}

People come to the world on equal terms, and it is known that people have equal rights in all areas of life. On the other hand, some groups of people cannot have the same rights as other people because of their social, physical and cognitive characteristics they have in society. Disabled people are an important part of the mentioned barrier groups (Subaşığlu, 2008). When genetically assessed, disability is defined as a biological disease (Demirbilek, 2013), and in the United Nations Declaration of Injuries, the disabled individual is described as "an individual who cannot do his or her own work due to any deficiency"(Öztürk, 2011).

One of the groups frequently encountered in disabled people is the hearing impaired individuals. Individuals with partial hearing loss in one or both ears are defined as hearing impaired individuals (Ozturk, 2011) Hearing impaired individuals face with many problems in their lives. For this reason, it negatively affects the health and quality of life of the hearing impaired individual (Agrawal, et. al., 2008). When addressed physically, the main problems of hearing-impaired individuals are balance problems in displaying basic kinetic movements such as running, walking, sitting, etc. (T. C. Ministry of National Education [MEB], 2010).

In conceptual terms, the concept of sport is a phenomenon that is aimed at winning the competition, which requires a physical, mental and technical effort, aesthetic sensation in the followers, intertwined with fields such as physiology, biomechanics and psychology (Çoban \& Ünveren, 2007). Participation in sports activities has many benefits in terms of the individual and it is emphasized in researches that participation in sport supports the mental development and maintains the psychological health (Şenyüz, 2013; De Moor et al., 2006; Şahin, Yetim, \& Çelik, 2012; Ströhle, 2009; Shepherd \& Unveren, 2007). As for the individuals showing a normal development, there are some psychological benefits of participation in the sports for disabled individuals as well. According to Yetim (2014), participating in sport events contributes to social roles of disabled people by arousing feelings of trust, discipline, competitiveness and friendship. According to Taşkın (2014), disabled people's participation in the sports increases the self-confidence level, supports the self-development and increases the motivation of life.

When considered conceptually, attention is considered as the head orchestra conductor of the brain. Because attention is the administrative bureau and regulatory center in which the brain accepts to learn. Attention also controls the distribution of mental energy in the brain. For instance, attention determines whether a student will concentrate on the teacher who is instructing or concentrate on the conversation with his classmate next to him. In addition to this, the high level of attention contributes to the long-term activeness of the mind on the work dealt with. On the other hand, the lack of attention leads to the production of the excuses to leave the job (Güllü, 2012). Research findings existing in the literature show that participation in the sports effects the attention skill positively (Asan, 2011; Dereceli, 2011). However, research findings evaluating the effects of sport involvement on attention skills of hearing-impaired individuals have been found to be limited. In this context, it is aimed in this research to compare the attention skills of hearing impaired individuals who do sports and who do not.

\section{METHOD}

\section{Research Model}

In this study, "Screening Model" which is a frequently used research model in education and social sciences has been used. The surveys conducted according to the screening model are carried out in order to determine the characteristics that have been the research topic of some demographic characteristics (age, sex, marital status, education level, income status, etc.) of large sample groups. In addition to this, researches which are conducted according to the screening model are evaluated as descriptive research (Can, 2014).

\section{Working Group}

135 children who play sport regularly and 98 children who do not have a regular sport habit, 233 hearing-impared individuals in total, who accommodate in the cities of Malatya, Elazı $\breve{g}$, Gaziantep and Istanbul, participated to the research. When the distribution of hearing-impaired individuals participating in the research is evaluated according to the places they reside, it's been determined that 
17 children who play sport and 9 children who do not play sport in Malatya, 21 children who play and 14 who do not in Elazığ, 23 children who play and 26 who do not in Gaziantep, and 74 children who play and 49 who do not in İstanbul participated to the research. When the distributions according to gender were evaluated, it was determined that 92 of the hearing impaired children who play sports were male and 43 were female, and 41 of the hearing impaired children who do not play sports were female and 57 were male.

\section{Bourdon Attention Test}

The Bourdon Attention Test was used to identify the attentional skills of hearing-impaired children participating in the study. The most recently used form of the Burdon Attention Test was developed by Benjamin Bourdon in 1955 and the test consists of two forms. The first one of these forms is applied by finding and marking certain letters among mixed letters. The second form is implemented by finding and marking some figures and shapes among mixed figures and shapes (Brickenkamp, 1975; Acta: Kaymak, 2003). In this study, letter finding method, which is the first form of the Bourdon Attention Test, was used. Before Burdon attention test was started, a brief information about the test was given to the children who formed the study group. Attention levels of the individuals are measured with Burdon Attention Test. This test can be applied to individuals whose age range is 9-20. In the test, the individuals who participated in the research are given letters that are randomly set on a page. These letters are set in a specific order on the page and there are 660 letters on each page. In an experimental page, there are 31 letters "a", 29 letters "g", 30 letters "b" and 29 letters "d". Individuals participating in the study are given 5 minutes for each section. Individuals who are participating to the research are said to underline the letters $\mathrm{a}, \mathrm{b}, \mathrm{d}$ and $\mathrm{g}$ on the page in front of them and mark only one letter when passing through a line. However, participants have to underline all the letters a, b, d and $g$ on the page. This situation is reminded to the participant before the test. After the test is completed, the test is evaluated by counting the lines (Yarımkaya et al., 2015). In the evaluation of the test, the correct answers given by the participants are taken into consideration and each correct answer is recorded as one point (Bozan \& Akay, 2012).

\section{Statistical Analysis}

SPSS 22.0 program was used in the analysis of the obtained data. Before analyzing the data on the Burdon Caution Test according to demographic variables, the normal distribution suitability was examined with the One Sample Kolmogorov-Smirnov test. At the end of the test, it was determined that the data on the Burdon Caution Test showed no normal distribution. For this reason, nonparametric analysis methods were used to compare the data of Burdon Caution Test according to demographic variables. The Mann-Whitney $U$ test was used to compare the data for the Burdon Attention Test for those with two sub-variables in the demographic variables (e.g. gender, malefemale). In Mann Whitney U test, the significance level was determined as $\mathrm{p}<0.05$.

\section{FINDINGS}

Table 1

Comparison of Participants' Attention Levels with Mann Whitney U-test According to Sporting Situations

\begin{tabular}{llllll}
\hline Sporting situation & $\mathrm{N}$ & Order Avg. & Order total & $\mathrm{U}$ & $\mathrm{P}$ \\
\hline Non-sports & 98 & 69.96 & 6856 & \multirow{2}{*}{2005} & \multirow{2}{*}{001} \\
Play sports & 135 & 151.15 & 20405 & & \\
\hline
\end{tabular}

Attention skills according to sport playing level of hearing impaired individuals were compared with Mann Whitney-U test. When the table1 is scrutinized, it is seen that the attention level of those who play sport $(\mathrm{SO}=151.15)$ are significantly higher than those who do not sports $(\mathrm{SO}=69.96)(\mathrm{p}<.05)$.

Table 2

Comparison of Attention Levels of Non-Sports Participants with Mann Whitney-U Test According to Gender

\begin{tabular}{llllll}
\hline Gender & $\mathrm{N}$ & Order Avg. & Order Total & $\mathrm{U}$ & $\mathrm{P}$ \\
\hline Female & 41 & 52.29 & 2144 & \multirow{2}{*}{1054} & \multirow{2}{*}{.408} \\
Male & 57 & 47.49 & 2707 & & \\
\hline
\end{tabular}


Attention levels according to the gender of the participants who do not play sport were compared with Mann Whitney-U test. When looked at the values of Females ( $\mathrm{SO}=52.29)$ and Males $(\mathrm{SO}=47.49)$, it was determined that there was no statistically significant difference between genders $(\mathrm{p}>0.05)$.

Table 3

Comparison of Attention Levels of Participants Who Do Sports with Mann Whitney-U Test According to Gender

\begin{tabular}{llllll}
\hline Gender & $\mathrm{N}$ & Order Avg. & Order Total & $\mathrm{U}$ & $\mathrm{P}$ \\
\hline Female & 43 & 80.59 & 3465.5 & \multirow{2}{*}{1436.5} & \multirow{2}{*}{010} \\
Male & 92 & 62.11 & 5714.5 & & \\
\hline
\end{tabular}

Attention levels of participants who do sports compared with Mann Whitney-U Test according to their gender. When the table is examined, it is observed that the attentional level of female participants $(\mathrm{SO}=80.59)$ is significantly higher than male participants $(\mathrm{SO}=62.11)(\mathrm{p}<0.05)$.

\section{DISCUSSION and CONCLUSION}

When the attention levels of the students participating in the research is compared according to their sporting status, it is concluded that the attention levels of the hearing-impaired individuals who play sports are significantly higher than the hearing-impaired individuals who do not play sport. It is thought that the benefits of participating to sport have positive effects on attention levels. The result of this conclusion can be thought to be due to the positive benefits of involvement in sports. According to Asan (2011: 38), children's participation in the sport improves attention as well as concentration skills. According to Bakır \& Aydoğan (2011), disabled individuals' participation in sport contributes to increase work efficiency and increase nerve-muscle activation when compared to sedentary individuals of the same age group. Empirical research findings in the literature also show that participation in sport influences attention development positively (Tunç, 2013, Adsı, 2010).

When the attention levels of the students who do not play sports were compared according to the gender variable, it was concluded that the attention level of both male and female participants are at similar level. In this context, it was concluded that gender is not a significant determinant of attention level in hearing-impaired individuals who do not play sports. In the research carried out by Karaduman (2004), it was found that the gender variable does not have a significant effect on attention skill. On the other hand, it has been found out in this research that gender is an important determinant for attention level in hearing impaired individuals. According to the findings, it was determined that the attention levels of female participants who play sports are significantly higher than male participants

As it is known, attention development is affected from some biolgical and physiological development units besides psycho- social development features (Asan, 2011). In this context, it can be considered that the level of attentiveness of the sedentary hearing impaired people does not differ according to the sex, due to the fact that both sexes are grown in similar social environments. The reason why the attention levels of hearing impaired individuals who do sport became in favor of female participants is because when compared to male participants, female participants involve in sport activities more often. In the study carried out by Rueda et. al. (2005), it was stated that the education provided by the society has a crucial role on the attention development of children.

As a result, when the findings obtained from the research were evaluated, it was determined that attention is high in favor of hearing impaired individuals with sports habits. Depending on the findings of the research and similar research findings in the literature, it can be concluded that participation in the sports is beneficial for the development of attention skills in hearing impaired individuals.

Acknowledgement: This study presented at 10 th International Physical Education, Sports and Physical Therapy Congress (ICPESPT2016) in November 18th-20th, 2016 in Firat University, Elazığ, Turkey

\section{REFERENCES}

Adsiz, E. (2010). Investigation of the effects of regularly observed sports on students in the elementary school age. (Unpublished master's thesis). Ege University, İzmir. 
Agrawal, Y., Platz, E. A., \& Niparko, J. K. (2008). Prevalence of hearing loss and differences by demographic characteristics Among US adults data from the national health and nutrition examination survey, 19992004. Archives of Internal Medicine, 168(14), 1522-1530.

Asan, R. (2011). The effect of eight weeks of table tennis exercise on the attention of children aged 9-13. (Unpublished master's thesis). Selçuk University, Konya.

Bakır, S., \& Aydoğan, H. (2011). Comparison of Simple Auditory Reaction Times between 12-14 Aged Football Players of Gençlerbirliği FC and Visually Impaired Students Who Are Involved in Sports and Sedentary. Selcuk University Journal of Physical Education and Sports Science, 3 (special issue), 151160.

Bozan, A.Y. (2012). The Effect of Attention Improvement Trainıng on The Primary School 5th Grade Students' Skills of Gatherıng Attention. Western Anatolia Educational Science Journal, 3(6), 53-66.

Brickenkamp, R., Bleck,I., Dzida, W., Heinrich, P., Hellwig, H.J., Krüger- Naumann, R., Rothe, R., Speck, D., Speck, R., \& Thiede, L. (1975). Handbuch psychologischer und paedagogischertests. Göttingen: Verlag für Psychologie.

Can, A. (2014). Quantitative data analysis in scientific research process with SPSS. (2. eds). Ankara: Pegem Academy

Çoban, B., \& Ünveren, A. (2007). Physical education and game teaching. Oğuzhan Zirek (Ed.). Ankara: Nobel Publication Distribution.

Demirbilek, M. (2013). The needs of mentally handicapped individuals and their families. Turkish Journal of Family Medicine and Primary Care, 7(3), 58-64.

De Moor, M. H. M., Beem, A. L., Stubbe, J. H., Boomsma, D. I., \& De Geus, E. J. C. (2006). Regular exercise, anxiety, depression and personality: a Population-Based Study. Preventive Medicine, 42(4), 273-279.

Dereceli, Ç. (2011). Investigating the effect of primary level I students with attention deficit and hyperactivity impairment on internal and external audit focus and attention levels in the Tai-Chi program. (Unpublished doctorate thesis). Ege University, İzmir.

Karaduman, B.D. (2004). The effect of attention training program on fourth and fifth grade primary school students'attention, self concept and achevement levels. (Unpublished doctorate thesis). Ankara University, Ankara.

Kaymak, S. (2003). Improving The Concentratıon Skıll of Chıldren Attending The Second and Third Classes of a Primary School. (Unpublished doctorate thesis). Ankara University, Ankara.

T.C. Ministry of Education. (2010). Why and how to integrate our schools manager, teacher and family guide. Ankara: General Directorate of Special Education Guidance and Counseling Services.

Öztürk, M. (2011). The fact of disabled in Turkey. Istanbul: MUSIAD Pocket Books.

Rueda, M.R, Rothbart, M.K, McCandliss, B.D, Saccomanno, L, \& Posner, M.I. (2005). Training, maturation, and genetic influences on the development of executive attention. Proceedings of the national Academy of Sciences of the United States of America, 102(41), 14931-14936

Ströhle, A. (2009). Physical activity, exercise, depression and anxiety disorders. Journal of Neural Transmission, 116, 777-784.

Subaşığlu, F. (2008). A research on "disability awareness" of information and document management departments of universities. The world of knowledge, 9(2), 399-430.

Şahin, M., Yetim, A. Z., \& Çelik, A. (2012). Physıcal Actıvıty and Sport as a Preventıve Factor ın Buıldıng Resilience. The Journal of Academic Social Science Studies, 5(8), 373-380.

Şenyüzlü, E. (2013). Analysis of the Effects of Sports Participation on Aggressive Behaviour Among University Students. (Unpublished master's thesis). Dumlupinar University, Kütahya.

Taşkın, R. (2014). No obstructions in sports. 2nd Internatıonal Physlcal Educatıon and Sports Congress for The Disabled, (p. 43-45), Batman.

Tunç, A. (2013). An investigation of attention levels of golf sports children. (Unpublished master's thesis). Selçuk University, Konya

Yarımkaya, E., Akandere, M., \& Topal, A. (2015). The effect of sprint training on children's attention. International Referee Sports Journal of Health and Medical Sciences, 5(14), 83-95.

Yetim, A.A. (2014). Sociological approach to disability sports. 2nd Internatıonal Physlcal Educatıon and Sports Congress for The Disabled, (p. 3-9), Batman. 


\section{TÜRKÇE GENIŞLETILMIŞ ÖZET}

Yapılan bu araştırmada, spor yapan işitme engelli çocuklar ile spor yapmayan işitme engelli çocukların dikkat becerilerinin bazı değişkenlere göre karşılaştırılması amaçlanmıştır. Araştırmaya Malatya, Elazığ, Gaziantep ve İstanbul illerinde ikamet etmekte olan, düzenli olarak spor yapan 135 ve düzenli olarak spor yapma alışkanlığı bulunmayan 98 çocuk olmak üzere toplam 233 işitme engelli birey katılmıştır. Araştırmaya katılan işitme engelli bireylerin, ikamet ettikleri illere göre dağılımları değerlendirildiği zaman, araştırmaya Malatya ilinden spor yapan 17, spor yapmayan 9 çocuk, Elazı̆̆ ilinden spor yapan 21, spor yapmayan 14 çocuk, Gaziantep ilinden spor yapan 23, spor yapmayan 26 çocuk, İstanbul ilinden ise spor yapan 74, spor yapmayan 49 çocuk katıldığ belirlenmiştir. Cinsiyetlerine göre dağılımları değerlendirildiği zaman, spor yapan işitme engelli çocukların 92'sinin erkek, 43'ünün kız olduğu, spor yapmayan işitme engelli çocukların ise 41'inin kız, 57'sinin ise erkek olduğu tespit edilmiştir.

Araştırmanın veri toplama aşamasında iki bölümden oluşan anket kullanılmışıı. Kullanılan anketin birinci bölümünde, katılımcıların demografik özelliklerini belirlemeyi amaçlayan kişisel bilgi formu yer almaktadır. Araştırmaya katılan işitme engelli çocukların sahip oldukları demografik özelliklerin belirlenmesinde kullanılan kişisel bilgi formu, uzman görüşü alınarak hazırlanmıştır. Veri toplama anketinin ikinci bölümünde ise katılımcıların dikkat becerilerini belirlemeyi amaçlayan test bulunmaktadır. Araştırmaya katılan işitme engelli çocukların dikkat becerilerinin tespit edilmesinde Bourdon Dikkat Testi kullanılmıştır. Bourdon Dikkat Testinin en son kullanılan biçimi 1955 yılında Benjamin Bourdon tarafından geliştirilmiş olup test iki formdan meydana gelmektedir. Bu formlardan birincisi belli harfleri karışık harfler arasında bulup işaretleme şeklinde uygulanmaktadır. İkinci form ise bazı figür ve şekillerin karışık figür ve şekiller arasından bulunup işaretlenmesi şeklinde gerçekleştirilmektedir (Brickenkamp, 1975; Aktaran: Kaymak, 2003). Yapılan bu araştırmada Bourdon Dikkat Testi'nin birinci formu olan harf bulma yönteminden yararlanılmıştır. Bourdon dikkat testine başlamadan önce, araştırma grubunu oluşturan çocuklara test hakkında kısa bilgi verilmiştir. Bourdon Dikkat Testi ile bireylerin dikkat düzeyleri ölçülmektedir. Bu test yaş aralığı 9-20 arasında bulunan bireylere uygulanabilmektedir. Testte araştırmaya katılan bireylere bir sayfa üzerinde gelişi güzel dizilmiş olan harfler verilmektedir. Bu harfler sayfa üzerinde belirli bir sıra ile dizilmiş olup her sayfada toplam 660 harf yer almaktadır. Deneme amaçlı olarak hazırlanan bir sayfada 31 tane "a" harfi, 29 tane "g" harfi, 30 tane "b" harfi ve 29 tane "d" harfi yer almaktadır. Testte araştırmaya katılan bireylere her bölüm için 5 dakika süre verilmektedir. Araştırmaya katılan bireylere bu süre içerisinde, önlerinde bulunan sayfada yer alan a, b, d ve g harflerinin altlarını kurşun kalem ile çizmeleri ve bir satısı gözden geçirirken sadece bir harfi işaretlemeleri gerektiği söylenmektedir. Ancak; katılımcılar mutlaka sayfada yer alan tüm a, b, d ve g harflerinin altını çizmek zorundadırlar. Bu durum, katılımcılara test öncesinde hatırlatılmaktadır. Test tamamlandıktan sonra çizgiler sayılarak testin değerlendirmesi yapılmaktadır (Yarımkaya, Akandere ve Topal, 2015). Testin değerlendirilmesinde, katılımcıların verdikleri doğru cevaplar dikkate alınmakta olup verilen her bir doğru cevap bir puan olarak kaydedilmektedir (Bozan ve Akay, 2012).

Elde edilen verilerin analizinde SPSS 22.0 programı kullanılmıştır. Burdon Dikkat Testine ilişkin veriler demografik değişkenlere göre analiz edilmeden önce normal dağılıma uygunluğu One Sample Kolmogorov-Smirnov testi ile incelenmiştir. Yapılan test sonucunda Burdon Dikkat Testine ilişkin verilerin normal dağılım göstermediği tespit edilmiştir. Bu nedenle, Burdon Dikkat Testine ilişkin verilerin demografik değişkenlere göre karşılaştırılmasında non-parametrik analiz yöntemleri kullanılmıştır. Demografik değişkenlerde iki alt değişkeni olanlar için (örneğin cinsiyet kadın-erkek) Burdon Dikkat Testine ilişkin verilerin karşılaştırılmasında Mann Whitney U testi kullanılmıştır. Mann Whitney $U$ testlerinde anlamlılık düzeyi $\mathrm{p}<0.05$ olarak belirlenmiştir.

Araştırmanın sonunda, spor yapma alışkanlığı bulunan işitme engelli bireylerin, dikkat becerilerinin spor yapma alışkanlığı bulunmayan (sedanter) işitme engelli bireylere kıyasla istatistiksel açıdan anlamlı düzeyde daha yüksek olduğu tespit edilmiştir. Spor yapma alışkanlığı bulunan işitme engelli çocuklar ile sedanter işitme engelli çocukların dikkat düzeyleri üzerinde bazı demografik değişkenlerin önemli birer belirleyici olduğu, buna karşılık her iki grupta da bazı demografik değişkenlerin dikkat düzeyini etkilemediği belirlenmiştir. Spor yapmayan işitme engelli çocuklarla kıyaslandığı zaman, spor yapan çocuklarda cinsiyet değişkeninin dikkat becerisini etkilediği belirlenmiştir. 
Sonuç olarak, dikkat becerisinin spor yapma alışkanlığı bulunan işitme engelli bireyler lehine yüksek olduğu tespit edilmiştir. Bunun yanında, sosyo-demografik değişkenlerin spor yapma alışkanlığı bulunmayan işitme engellilerin dikkat becerileri üzerinde anlamlı etkilere sahip olduğu, buna karş1lık sosyo-demografik değişkenlerin spor yapma alışkanlığı bulunan işitme engelli bireylerin dikkat becerilerini anlamlı düzeyde etkilemediği bulunmuştur. Araştırma elde edilen bulgular ve literatürde yer alan benzer araştırma bulgularına dayanılarak, işitme engelli bireylerde dikkat becerisinin geliştirilmesi için spora katılımın faydalı olacağı söylenebilir. 